\title{
Exploring the links between interdependence, team learning and a shared understanding among team members: the case of teachers facing an educational innovation
}

Citation for published version (APA):

Runhaar, P., Ten Brinke, D., Kuijpers, M., Wesselink, R., \& Mulder, M. (2014). Exploring the links between interdependence, team learning and a shared understanding among team members: the case of teachers facing an educational innovation. Human Resource Development International, 17(1), 67-87.

https://doi.org/10.1080/13678868.2013.856207

DOI:

10.1080/13678868.2013.856207

Document status and date:

Published: 01/01/2014

Document Version:

Version created as part of publication process; publisher's layout; not normally made publicly available

Document license:

CC BY-SA

Please check the document version of this publication:

- A submitted manuscript is the version of the article upon submission and before peer-review. There can be important differences between the submitted version and the official published version of record. People interested in the research are advised to contact the author for the final version of the publication, or visit the DOI to the publisher's website.

- The final author version and the galley proof are versions of the publication after peer review.

- The final published version features the final layout of the paper including the volume, issue and page numbers.

Link to publication

\section{General rights}

Copyright and moral rights for the publications made accessible in the public portal are retained by the authors and/or other copyright owners and it is a condition of accessing publications that users recognise and abide by the legal requirements associated with these rights.

- Users may download and print one copy of any publication from the public portal for the purpose of private study or research.

- You may not further distribute the material or use it for any profit-making activity or commercial gain

- You may freely distribute the URL identifying the publication in the public portal.

If the publication is distributed under the terms of Article 25fa of the Dutch Copyright Act, indicated by the "Taverne" license above, please follow below link for the End User Agreement:

https://www.ou.nl/taverne-agreement

Take down policy

If you believe that this document breaches copyright please contact us at: pure-support@ou.nl

providing details and we will investigate your claim.

Downloaded from https://research.ou.nl/ on date: 26 Apr. 2023 


\section{Runhaar, P., Brinke, D. ten, Kuijpers, M., Wesselink, R., \& Mulder, M. (2014) Exploring the links Between...}

Article in Human Resource Development International · January 2014

CITATIONS

0

1 author:

Piety R. Runhaar

Wageningen University \& Research

30 PUBLICATIONS 252 CITATIONS

SEE PROFILE

Some of the authors of this publication are also working on these related projects: 
This article was downloaded by: [77.163.182.74]

On: 11 January 2014, At: 07:11

Publisher: Routledge

Informa Ltd Registered in England and Wales Registered Number: 1072954 Registered

office: Mortimer House, 37-41 Mortimer Street, London W1T 3J H, UK

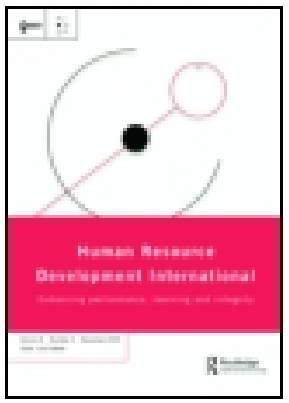

\section{Human Resource Development International}

Publication details, including instructions for authors and subscription information:

http:// www.tandfonline.com/loi/ rhrd20

\section{Exploring the links between} interdependence, team learning and a shared understanding among team members: the case of teachers facing an educational innovation

Piety Runhaar ${ }^{a}$, Diane ten Brinke ${ }^{b}$, Marinka Kuij pers ${ }^{c}$, Renate Wesselink $^{a} \&$ Martin Mulder ${ }^{a}$

${ }^{a}$ Chair Group Education \& Competence Studies, Wageningen UR (University \& Research Centre), The Netherlands

${ }^{b}$ Regional Community College of Twente (ROC van Twente), The Netherlands

c Open University, Scientific Centre for Teachers Research, Heerlen; The Hague University of Applied Science (Haagse Hogeschool), The Netherlands Published online: 11 Dec 2013.

To cite this article: Piety Runhaar, Diane ten Brinke, Marinka Kuijpers, Renate Wesselink \& Martin Mulder, Human Resource Development International (2013): Exploring the links between interdependence, team learning and a shared understanding among team members: the case of teachers facing an educational innovation, Human Resource Development International, DOI: 10.1080/13678868.2013.856207

To link to this article: http:// dx. doi.org/ 10.1080/ 13678868.2013.856207

\section{PLEASE SCROLL DOWN FOR ARTICLE}

Taylor \& Francis makes every effort to ensure the accuracy of all the information (the "Content") contained in the publications on our platform. However, Taylor \& Francis, our agents, and our licensors make no representations or warranties whatsoever as to the accuracy, completeness, or suitability for any purpose of the Content. Any opinions and views expressed in this publication are the opinions and views of the authors, and are not the views of or endorsed by Taylor \& Francis. The accuracy of the Content should not be relied upon and should be independently verified with primary sources of information. Taylor and Francis shall not be liable for any losses, actions, claims, 
proceedings, demands, costs, expenses, damages, and other liabilities whatsoever or howsoever caused arising directly or indirectly in connection with, in relation to or arising out of the use of the Content.

This article may be used for research, teaching, and private study purposes. Any substantial or systematic reproduction, redistribution, reselling, loan, sub-licensing, systematic supply, or distribution in any form to anyone is expressly forbidden. Terms \& Conditions of access and use can be found at http://www.tandfonline.com/page/termsand-conditions 


\title{
Exploring the links between interdependence, team learning and a shared understanding among team members: the case of teachers facing an educational innovation
}

\author{
Piety Runhaar $^{\mathrm{a} *}$, Diane ten Brinke ${ }^{\mathrm{b}}$, Marinka Kuijpers ${ }^{\mathrm{c}}$, Renate Wesselink ${ }^{\mathrm{a}}$ and \\ Martin Mulder ${ }^{\mathrm{a}}$ \\ ${ }^{a}$ Chair Group Education \& Competence Studies, Wageningen UR (University \& Research Centre), \\ The Netherlands; ${ }^{b}$ Regional Community College of Twente (ROC van Twente), The Netherlands; \\ ${ }^{c}$ Open University, Scientific Centre for Teachers Research, Heerlen; The Hague University of \\ Applied Science (Haagse Hogeschool), The Netherlands
}

(Received 18 April 2013; accepted 23 September 2013)

\begin{abstract}
Teams are increasingly regarded as the building blocks of organizations, for teams of employees are better able to deal with complex problems and ever-changing demands than individual employees. The effectiveness of teams depends, to a large extent, on team members learning together and developing a shared understanding of the complex problems they face. As a way to meet the call for more research on conditions that foster team learning, we conducted a multiple case study in which three teacher teams participated. The data showed links between teachers' goal interdependence, their engagement in team learning activities, like observing each other and preparing lessons together, and a shared understanding of the educational innovation they had to implement. Theoretical and practical implications are discussed.
\end{abstract}

Keywords: task and goal interdependence; team learning; workplace learning; competence-based education; teacher teams

\section{Introduction}

Teams are increasingly viewed as the building blocks of organizations. More specifically, due to globalization and technological developments, organizations have to adapt and improve their products and processes continuously. Because teams are better able than individuals to manage complex problems and to deal with ever-changing demands, the implementation of team-based structures is regarded as an effective way to help organizations to become reflexive and flexible entities (e.g. Decuyper, Dochy, and Van de Bossche 2010; Wilson, Goodman, and Cronin 2007).

The effectiveness of teams can be attributed, to a large extent, to the degree to which team learning takes place: due to interactions between team members, knowledge and skills gathered by one team member can be transferred to other team members (van Woerkom and Croon 2009). This, in turn, enables teams to develop a shared understanding of the complex problems and demands they are confronted with in order to find effective ways to deal with those problems and demands (Van den Bossche et al. 2006). Team learning has thus become crucial to organizations' success (Zaccaro, Ely, and Shuffler 2008).

*Corresponding author. Email: piety.runhaar@wur.nl 
While the importance of team learning is widely acknowledged, empirical studies are still needed to get more insight into the exact nature of team learning (Decuyper, Dochy, and Van de Bossche 2010), to understand how it relates to a shared understanding among team members (Van den Bossche et al. 2006) and to uncover the conditions that enable team members to learn in interaction with each other (Tillema 2005). This especially applies to HRD literature, where, traditionally, the focus has been on organizational and individual learning processes (McCarthy and Garavan 2008). With our case studies on learning within teacher teams in vocational education and training (VET) institutions, we aim to contribute to this field of research. As we will describe in more detail later on, this research context is interesting because of the complex demands (i.e. educational innovations) teachers are facing right now (Lodders 2013).

In team learning literature, team learning is both conceived of as an outcome, like a change in repertoire or performance (e.g. Wilson, Goodman, and Cronin 2007) as conceptualized as a process, like the activities team members undertake to obtain and process information in order to adapt and improve (e.g. Edmondson 1999). In our study, we include both. Concerning the process, in line with employees' learning in general (Lohman 2005) and teachers' learning specifically, we examine the workplace learning within teacher teams. Workplace learning is defined as learning which is embedded in the tasks and work of employees and which is relatively unstructured, informal and mostly initiated by the employees themselves (e.g. Marsick and Watkins 2001). A main assumption within this perspective on learning is that the learning is personal and representative of the person's own work situation and therefore enhances the chances that current practice will be adapted. Workplace learning can take the form of individual learning activities like reflection and keeping up-to-date, and of interpersonal learning activities like knowledge sharing and collaboration (e.g. Bakkenes, Vermunt, and Wubbels 2010; Kwakman 2003). Given our intention to gain more insights into team learning, we focus on the latter category. As such, with team learning, we refer to team members learning in interaction with each other at the workplace. Concerning, the outcome of team learning, we examined the links between team learning and the shared understanding among teachers of the educational innovation at hand. Finally, we aimed to find out how team characteristics were related to the degree to which teachers engaged in team learning activities. More specifically, we explored the roles of task interdependence - defined as the work flowing from one team member to another in such a way that the task performance of one member depends on the task performance of the other (Kiggundu 1983) - and goal interdependence - referring to the extent to which team members have to contribute to the achievement of group goals (Deutsch 1973) - since these are considered factors that determine the quality of interaction among team members to a large extent (Van der Vegt and Janssen 2003) and presumably the degree of interpersonal learning as well.

In sum, our central research question was: 'To what extent and how do task and goal interdependence between teachers, their engagement in team learning activities and a shared understanding among teachers of the innovation relate to each other?'

By answering this question we aim to make theoretical as well as practical contributions. Related to the first, as already mentioned above, with our study we aim to respond to the call for more knowledge on learning on the team level, especially concerning conditions that can enhance team members' engagement in interpersonal learning activities. Moreover, we expect that on the base of our findings, we can formulate practical recommendations for managers and HRD practitioners who have to facilitate teams in dealing with challenges, like innovations, and who aim to stimulate team learning within their organizations. 
Before we will describe the theoretical perspectives and expectations that guided our study, we will elaborate more on the research context and place this in a broader, international perspective.

\section{Research context: Dutch VET institutions}

VET institutions in various western countries - as main suppliers of graduates for the labour market (Van den Berg, Meijers, and Sprengers 2007) - are currently implementing competence-based education (CBE), in which competencies needed in practice form the starting point for curriculum development instead of academic disciplines (Wesselink et al. 2010). CBE is implemented for several reasons, of which some are related to the improvement of the transition from education to the labour market and others to considerations regarding insights from learning psychology (Biemans et al. 2004). To start with the first, the rapid changes in societies and technologies require employees at all levels and all stages of their career to be willing to learn continuously and contribute to new developments. Hence, next to enough knowledge, students have to acquire a combination of skills, and attitudes which they need for effective performance, and continuous career development (e.g. Seezink and Poell 2010). As a consequence, the emphasis in educational programmes has shifted from pure knowledge acquisition to career guidance, coaching and competence development (e.g. Kuijpers, Meijers, and Gundy 2011). Moreover, new psychological insights into learning have changed the way educators think about the way students can best develop their competence. Parallel to current conceptualizations of employees' learning, student learning is nowadays conceived of as a process in which students actively construct their knowledge together with others (McLaughlin 1997). Hence, in CBE, students develop competencies by building meaningful relationships between knowledge, skills and attitudes in professional practice. This in turn can be viewed as a means to increase students' motivation to learn and hence to enhance their achievements (Schaap, Baartman and De Bruijn 2012).

CBE is implemented in many European countries (De Bruijn 2012) - 'Competence' is included in the European Qualification Framework - and comparable developments (like outcome-based education) are being implemented in other parts of the world, for example, Africa and South America (Mulder, Weigel, and Collins 2007). The CBE concept consists of the following principles (Wesselink et al. 2007, 2010):

(1) The competencies that are the basis of the study programme are defined;

(2) Professional core problems are the organizing unit for (re)designing the curriculum (learning and assessment);

(3) Competence development of students is assessed before, during and after the learning process;

(4) Learning activities take place in various authentic situations;

(5) In learning and assessment processes, knowledge, skills and attitudes are integrated;

(6) Self-responsibility and (self-)reflection of students are stimulated;

(7) Teachers, both in school and practice, balance their roles as coaches and experts; and

(8) A basis is established for a lifelong learning attitude among students.

The degree, to which schools succeed in making the shift towards a new educational concept, depends to a large extent on the competence of teachers (e.g. Rivkin, Hanushek, 
and Kain 2005). Concerning the transition to CBE, teachers are expected to fulfil other roles than they are used to (e.g. coach and tutor) and to apply other pedagogical approaches and methods. In The Netherlands, this is the main reason why the implementation does not go smoothly (Sturing et al. 2011); teachers often do not have a clear understanding of what CBE exactly encompasses and how it could be best translated into their practice. Hence, the learning of teachers in order to prepare themselves for these new roles has become increasingly important for schools and as such has become a recurrent item in research (e.g. Seezink and Poell 2010).

Like in other countries (Park, Henkin, and Egley 2005), Dutch VET institutions are increasingly implementing team-based organization structures. Instead of being responsible for instruction in one or two subjects, teachers are part of an interdisciplinary team, in which they need to collaborate with each other to develop and implement educational programmes, like hairdressing or construction (e.g. Wesselink et al. 2010). The importance of team learning thus has become increasingly important for teachers.

\section{Theory and expectations}

In this section, we explore, using theory and empirical evidence, whether and how interdependence, team learning activities and a shared understanding of the principles underlying $\mathrm{CBE}$ among teachers within teams are likely to be related to each other.

\section{Team learning and a shared understanding of CBE-principles}

Teachers make sense of new educational concepts from their unique frames of reference. Therefore, one teacher's interpretations of educational principles can differ from another's (see, for example, Coburn (2004)). These differences in understanding can in turn lead to teachers putting the principles into practice in different ways, generally resulting in poor implementation (Spillane, Reiser, and Reimer 2002). Hence, a shared understanding is needed for successful implementation.

Development of a shared understanding of $\mathrm{CBE}$, however, implies that at least some of the teachers have to adjust their assumptions and beliefs about teaching and their own role as a teacher (Seezink and Poell 2010). For example, teachers have to shift their main orientation from the subject matter to the learning processes of the students.

It is known that changing assumptions which underlie daily practice is one of the most difficult things to do. The reason is that assumptions make life predictable and understandable (e.g. Griffin, Shaw, and Stacey 1998), and that changing them might lead to feelings of failure and insecurity (Coburn 2004). As a result, people are often reluctant to engage in learning activities which are explicitly aimed at questioning assumptions (van Woerkom 2004). However, reflection on assumptions and beliefs and even a change of assumptions can occur when expectations are not met (for instance, when a teacher notices an unusual response of students to a common instruction method) or when one is confronted with new kinds of information or ideas that do not fit with one's frame of reference (for instance, when a teacher who is accustomed to traditional, teacher-oriented instruction enters a classroom where students work and are coached in small groups) (cf. Nisbett and Ross 1980). In addition, new and 'disconfirming' information will easier lead to reflection on and changing of beliefs when this information is personal and representative of one's own work situation (Chinn and Brewer 1993). It is because of these reasons that learning, which takes place at the workplace, in interaction with colleagues, is 
nowadays regarded as more effective compared to 'offsite' and 'formal' ways of learning, like a course or training, provided from experts outside the school (e.g. Putnam and Borko 2000; Smith and Gillepsie 2007). That is, because the possibilities and restrictions of teachers' specific work contexts are often not taken into account, it is difficult for teachers to translate the content of courses into their daily practices. Moreover, while the predominant passive role of teachers during formal courses, hinders the transfer of knowledge to practice, workplace learning activities, which do stimulate teachers to reflect on and adjust their beliefs, are more effective in helping teachers to implement new pedagogical insights into their practice (Meirink et al. 2010; Bakkenes, Vermunt, and Wubbels 2010).

The insights into the beneficial effects of learning at the workplace are, of course, not unique to schools. In fact, it is a widespread belief among organizational scientists and researchers in the field of HRD or adult learning that the knowledge and insights that professionals need to continuously develop themselves, are embedded in their daily practice. These notions are, for instance, reflected in theories on 'communities of practice' or 'organizational learning' (see for an overview Tynjälä (2012)).

Based on the above-mentioned theoretical insights and empirical findings, in our study, we explored whether and how team learning and a shared understanding of CBE among teachers, were related.

\section{Task and goal interdependence and team learning}

Although teachers in VET institutions increasingly have to work in teams, this is not to say that learning automatically occurs within these teams. In schools, teachers have long been used to working autonomously and in isolation, which impedes interaction (Silins and Mulford 2002) and consequently hinders teachers to learn from each other. Different authors have already stressed that interdependence among team members is at the heart of teamwork (Decuyper, Dochy, and Van de Bossche 2010) and specifically needed for learning to occur (e.g. Little 2003). However, still more knowledge is needed on the exact nature of this relationship between interdependence and learning (Meirink et al. 2010).

For two reasons we expected that task and goal interdependence could foster teachers' engagement in team learning activities. The first reason is that interdependence in itself influences the degree of interaction between team members (Campion, Medsker, and Higgs 1993), which can be considered an important prerequisite for learning together with colleagues. Interaction between colleagues enhances the exchange of ideas, experiences and practices, which in turn may lead to reflection on one's own practice and underlying assumptions (Meijrink et al. 2009). The second reason is that interdependence influences the quality of interaction. Task interdependence leads to employees feeling greater responsibility for each other's task outcomes (Kiggundu 1983), and to team members seeking and giving each other advice when confronted with problems (e.g. Wageman 2001). It is logical to expect that under these circumstances, teachers will be more likely to engage in social learning activities despite the risk of being 'vulnerable'. Concerning goal interdependence, research has shown that when people perceive that their goals are positively related, they are motivated to find manners in which mutual goals can be achieved and to resolve issues for mutual benefits. To this end, they aim to integrate their ideas (Deutsch 1973). Empirical studies have shown that goal interdependence is positively related to open-minded discussion and diverse views (e.g. Deutsch 1973; Johnson and Johnson 1989). We expected that these circumstances would serve as a climate in which teachers dare to be vulnerable and hence to engage more in team learning activities. 


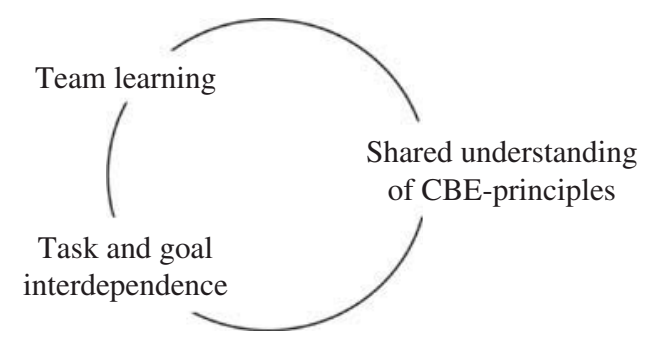

Figure 1. Summary of expectations.

\section{$A$ shared understanding of CBE-principles and interdependence}

As discussed earlier, we developed arguments for the expectation that the higher the task and goal interdependence between teachers, the more those teachers would engage in team learning activities and consequently the higher the degree of a shared understanding of CBE-principles among those teachers would be. This reasoning might well be too simplistic in the sense that these three phenomena may also be interrelated the other way around. In line with Savelsbergh, van der Heijden, and Poell (2009), it can also be the case that learning within teams leads to clarification and awareness of the teams' goals and interdependency of tasks. In that case, we may also expect that learning which results in a clearer understanding of CBE-principles leads to increased awareness of teachers' common goals and interrelated tasks in reaching these goals. Support for this expectation can be found in the observation that schools differ from each other in the degree to which CBE is implemented (Wesselink et al. 2007); for example, the level of integration of knowledge, skills and attitudes in the curriculum - an important feature of CBE - may be low, in that it sometimes occurs, or high, in which integration occurs in all learning and assessment procedures. In line with this, it is likely that teachers' tasks will work more separate from each other in the early stages of implementation than in later stages when integration is completed. In this sense, increased understanding of CBE-principles might lead to greater awareness of interdependencies.

In sum, we explored the associations between the three study variables, as visualized in Figure 1.

\section{Research design and data collection and analysis}

\section{Case study research}

Given the exploratory nature of our study, we opted for a parallel comparative case-study design as described by Yin (2003). This design enabled us to get an in-depth insight into team learning activities and their origins. In order to increase the ecological and internal validity of the findings, we included three different teams from one VET institution in the research. Teams participated on voluntary base. Because the teams within this institution were allowed to decide for themselves, albeit within a restricted range, when and how to start with the implementation of competence-based learning, their start dates differed. In addition, teams were free to use materials from external experts or to develop their own materials.

The research consisted of two distinct steps. First, for each team, we measured our study variables: the amount and content of a shared understanding of CBE; the amount and types of team learning activities that occurred; and the amount and form of task and goal interdependence between teachers. Within this step, we constructed a data matrix (Table 4) and included teams' ratings on each variable - a 'score' of 'low', 'moderate' or 
'high' (We will explain how we did this exactly below.). This strategy enabled us, in the second step, to conduct a 'cross-case analysis' with the aim of exploring whether and how our study variables relate to one another (Miles and Huberman 1994).

The size and response rates of teams differed: Team 1 consisted of 13 teachers, of whom 8 participated $(62 \%)$; Team 2 consisted of 11 teachers, of whom 9 participated $(82 \%)$; Team 3 consisted of 6 teachers and delivered 4 participants $(67 \%)$. When asked why they refused to participate, teachers reported that this was because of a lack of time.

The group of respondents consisted of 12 men and 9 women; their average age was 51 $(\mathrm{SD}=8.8)$. The teachers had an average of 22 years of experience in education $(\mathrm{SD}=8.3)$. These characteristics did not differ across the three teams.

\section{Interviews and coding of data}

Semi-structured interviews were conducted with individual teachers to get a rich insight into the experiences of the participants. The topics of the interviews are described below. The interviews were recorded and transcribed and analysed by two researchers, who clustered the answers using an interview guideline. The researchers coded the material independently from each other in order to increase the reliability of the results (Åkerlind 2005), and deliberated in case of different interpretations.

\section{Shared understanding of $C B E$}

We first assessed the individual teachers' understanding of CBE-principles, and then measured the agreement among teachers within the teams.

To measure teachers' understanding of CBE, two open questions were asked: 'What does CBE mean to you?' and 'What are the main principles, in your view?'. In order to code the teachers' answers, we used the list of main CBE-principles we referred to in the introduction and which was developed by Wesselink et al. (2007, 2010). The first principle, namely, 'The competencies that are the basis of the study programme are defined', was left out since this was a given for all Dutch vocational study programmes.

Second, we determined the degree of shared understanding on the basis of the amount of principles that were shared among the majority of team members. We did this in two steps. First, we counted the amount of principles per teacher. We concluded a low average number in case teachers named fewer than four principles, and a high number in the case of more than four principles. Second, we determined the agreement. Agreement meant that at least $50 \%$ of the teachers mentioned the same principle. We concluded low agreement in case of fewer than four principles and high agreement where there was agreement on more than four principles. The combination of these criteria led us to qualify the teams as low ('-', low average individual understanding and low agreement), moderate ( ' + /-', low average individual understanding but high agreement) and high (' + ', high average individual understanding and high agreement).

\section{Team learning}

In order to determine the degree to which the teachers engaged in team learning activities, we started with the open question 'What learning activities did you undertake to get a clear picture of what competence-based education is and how it should be put into practice?'. Using the literature (Bakkenes, Vermunt, and Wubbels 2010; Kwakman 
2003), we then presented a list of possible interpersonal learning activities. The list consisted of the following items:

(1) observing colleagues

(2) cooperating (e.g. preparing lessons or assignments)

(3) information meetings (e.g. during team meetings) and

(4) informal talk between teachers.

Respondents were asked to tell to what degree they made use of the different learning activities on a three-point scale, with 1 ('almost never'), 2 ('sometimes') and 3 ('very often') (represented as '-', ' +/-' and ' +', respectively).

\section{Task and goal interdependence}

To determine the amount of task and goal interdependence, we formulated open questions, based on the definitions and operationalization (i.e. questionnaire items) of the two forms of interdependence put forward by Van der Vegt, Emans, and Van de Vliert (1998) and Deutsch (1973), respectively. Concerning task interdependence, we asked the following: 'To what extent do you depend on others in order to perform your own task well? Do you, for example, need information, advice, or materials from your colleagues to carry out your own tasks?' Answers were coded 'low', meaning teachers can work independently and do not need information from others; 'moderate', meaning it would be better if information from colleagues was present, but that teachers can also manage without; and 'high', meaning that teachers really need information and deliberation in order to carry out their own tasks properly. Concerning goal interdependence, we asked two related questions: 'To what extent does a collective goal exist within your team?' and 'To what extent do team members call each other to account for their contributions to the collective goal?' Answers were clustered in three categories: 'low' ('-'), meaning that there is no clear goal in the view of the respondent; 'moderate' (' $+/-$ '), meaning that there is a common goal according to the respondent, but that team members do not call each other to account for their contributions to goal achievement; and 'high' (' + '), referring to a clear common goal and teachers calling each other to account.

\section{Results}

We first give a short description of each team and discuss the study variables for each team separately. We then summarize the general findings and elaborate on the relationships between the study variables in the cross-case analysis section.

\section{Team 1}

In contrast to the other two teams that participated in the study, this team was responsible for providing training in three different occupational areas, namely, secretarial, financial and commercial training. The implementation of CBE started two years before our study was conducted. In the first year, the team was informed about the goals and features of CBE during information meetings, and workshops were organized to familiarize teachers with the concept of CBE. In the second year, the team implemented projects in which students had to integrate knowledge, skills and attitudes, and different subject matters, to solve authentic problems representative of the occupation. These integrative projects were 
developed by an external advisory agency. A part of the curriculum was organized around these integrative projects (on average three hours, three times every week). These projects were guided by two teachers. Attempts were made to ensure that at least one of the teachers attended all meetings related to one project. Not all teachers from this team were involved in integrated projects. Team meetings occurred formally (about three or four times each year) and informally (teachers met in the mornings before lessons started and discussed relevant issues related to lessons and students).

\section{Shared understanding of $C B E$}

Large differences existed between the teachers concerning the 'richness' of their descriptions of $\mathrm{CBE}$, and thus the number of principles they named. Five out of eight descriptions included three or fewer principles. For example, according to one teacher, CBE was mainly a way to create 'tailor-made' education:

CBE means that students can accelerate or do some extra courses on the basis of their competencies. (T7)

The descriptions of three teachers encompassed five or six principles. For example:

As I see it, the goal of CBE is that you prepare the student for the tasks and dilemmas they will meet once they go to work ... that we integrate different disciplines ... stimulate students to reflect on their work attitude; for example, when they had difficulties I discussed how they coped with the problems ... even when I do a lesson on fundamental theory, I always try to highlight its relevance to practice. (T2)

There was low agreement among teachers about the principles; six out of the eight respondents $(75 \%)$ agreed on three principles (1, 3 and 4). As one of the teachers illustrated:

When we occasionally talk about our experiences with $\mathrm{CBE}$, you discover that everyone has his/her own image of CBE. (T2)

\section{Team learning}

On average, teachers reported low levels interpersonal learning activities. One of the teachers said:

We lack the time to put enough energy into developing new materials and discussing with each other what CBE encompasses ... we are all too busy with our teaching tasks. (T3)

Most teachers (seven out of eight) expressed the need for concrete examples of methods and materials that could help them make the transition from theory to practice. Teachers mostly contacted colleagues in the same discipline and asked them for help or advice. These colleagues, however, were not automatically members of the team. For example, one teacher said: 
It can be concluded that learning with colleagues during work occurred occasionally in this team and was not stimulated in a systematic way. Exemplary in this respect was the perceived lack of team meetings. As one teacher explained:

It would be nice to share knowledge and experiences with colleagues from other disciplines

... but we never meet so this never happens. (T4)

And:

I guess that for us to develop high-quality CBE-based education, our learning and development needs to be structured ... we need at least half a day each week to deliberate on CBE, what it means, and how we can integrate it into our curriculum. (T1)

\section{Interdependence}

On average, teachers reported moderate levels of task interdependence. Four out of the eight teachers reported that they could do their work fine without help or information from others (low task interdependence), and two teachers viewed the task interdependence as moderate because of the integral projects or their specific role (mentor or internship coordinator). Two teachers reported high task interdependence. One did so because he was new in the team and still needed a lot of information from colleagues, and the other because she assumed that it is only possible to construct a high-quality educational programme if the various lessons and projects are linked to each other:

I think that in time all colleagues within the team will gain the insight that education gets better if the different parts of the curriculum are connected to each other ... and consequently that we need information about what theory and practical skills we all offer in our lessons in order to create a meaningful project. (T4)

On average, a low level of goal interdependence was experienced in this team. For example:

Well, the goal is to implement competence-based education. But everyone is focused on his own projects, so I don't really see this as a common goal. (T2)

Only two out of the eight teachers experienced a moderate or high level of goal interdependence. For example:

In this team we all aim at getting the best out of our students. I think that if I noticed that a colleague was not pursuing this goal, I would call him or her to account. (T4)

It may be concluded that within this team, on average, moderate levels of task interdependence and low levels of goal interdependence were experienced. This probably had to do with the fact that the team was responsible for three different programmes and, therefore, consisted of subgroups of teachers who all focused on their own specific tasks.

A summary of this team's scores is presented in Table 1. 
Table 1 . Summary of scores team 1 .

\begin{tabular}{lcccc}
\hline \multicolumn{2}{l}{ Understanding of CBE } & \multicolumn{2}{c}{ Team learning } & \multicolumn{2}{c}{ Interdependence } \\
\hline Individual & - & Interpersonal learning activities at workplace & - & Task \\
Shared & - & & Goal & - \\
\hline
\end{tabular}

\section{Team 2}

This team provided legal training and was one of the first teams in the VET institution to implement competence-based learning (four years before the study was conducted). The team used integrated projects in which different disciplines came together. These projects were developed by teachers from this team, and most teachers were involved in supervising one or more projects. Most of the teachers performed the role of coach, which meant that they monitored and guided one or more groups of 10 students in a specific year. Half of the curriculum was organized in 'traditional' lessons, and half was organized around integrated projects. The students worked on projects under the guidance of the coach two times a week, for three hours each time. Once a week, students worked on the project on their own, also for three hours. There were weekly (formal) meetings, one for the whole team and one for coaches of students in specific years, at which the students and projects were discussed.

\section{Shared understanding of $C B E$}

On average, the number of principles that we detected in teachers' descriptions of CBE could be qualified as moderate. Five out of the nine teachers named four, and one named six, principles (3.8 principles per teacher on average). For example:

That we are not only focused on the knowledge students need ... but on the total package ... the integration of knowledge, attitude, skills, and behaviour that is needed to be able to perform well later on in practice...As a teacher you fulfil different roles in order to achieve this goal. Sometimes you give a lecture on theory and sometimes you stimulate students to reflect on their behaviour. (T16)

Three out of the nine teachers named two or three principles. For example:

That students are not only offered theory, but that they have to apply this in the projects as well. (T10)

The agreement among teachers was also high; there was agreement among six teachers $(67 \%)$ on five principles $(1,3,4,5$ and 6$)$.

\section{Team learning}

The degree to which interpersonal learning activities at work took place within team 2 could be qualified as moderate. Learning activities occurred on a regular basis, especially when they were directly embedded in the work. Discussion of CBE-related issues occurred very often in this team (six out of the nine teachers score high). This happened 
informally and unplanned but also often during information meetings for coaches of students in specific years. As one teacher stated:

In our coaches group we discuss what went well and what went wrong, how we can organize a project in a different way next time, etc... I must admit I only discuss these issues with colleagues from the same year, not with colleagues from higher years. That would be too much and too complicated for me. (T12)

Observing each other in lessons and giving each other feedback afterwards almost never occurred. For example:

I often ask colleagues to attend my lessons ... to see what I am doing and to give feedback ... but no one ever replies. Critical reflection is still 'not done' in schools apparently. (T14)

When teachers did observe each other, this occurred in the case of student teachers who had to collect feedback for their course of study, or when it was not organized but inherent in the work. As one of the teachers explained:

In the integrated projects we automatically see each other acting and interacting with students. Here you learn from each other in a natural way. (T9)

\section{Interdependence}

Task interdependence was qualified as high by seven out of the nine teachers. They all referred to the development and to the execution of integrated projects. Teachers needed to know, for example, the content provided by each other to students, or on the basis of what criteria the different aspects of the assignments had to be approved. Teachers experienced little task interdependence related to their own lessons.

Goal interdependence felt to be high (six out of nine) or moderate (three). Most teachers had the impression that they shared the same goal of raising students' achievement and preparing students for their future role in practice. At the same time, teachers differed from each other in terms of their tendency to call each other to account. For example:

It happens that we as colleagues make different decisions. For example, a colleague allows students to hand in their work a week late while I insist on the deadline. While I think this is wrong, I still find it difficult to call this colleague to account for it .... I think employees are more used to calling colleagues to account in profit organizations than in schools. (T10)

An overview of this team's scores is presented in Table 2.

Table 2. Summary of scores team 2 .

\begin{tabular}{lcccc}
\hline Understanding of CBE & Team learning & \multicolumn{2}{c}{ Interdependence } \\
\hline Individual & $+/-$ & Interpersonal learning activities at workplace $+/-$ & Task & Goal + \\
Shared & + & & Goal \\
\hline
\end{tabular}




\section{Team 3}

This was the smallest team, consisting of only six teachers. In practice, the team formed a part of a larger team that was located in another part of the building, but informally worked as an independent team. The team provided secretarial training; it started to implement CBE, similar to team 2, about four years before this study was conducted. The team used integrated projects that were developed by an external advisory agency. All teachers were mentor of one or more classes. The higher the level of the training, the larger the space allocated to integrated projects within the whole curriculum, with the number of hours varying from 5 to 8 hours a week. These projects were guided by one teacher in the first and last hour of the period. In between, students worked independently with one teacher who was available on demand. Until shortly before the study began, teachers met every week to discuss general issues, CBE-related issues, or students. This frequency was changed to once a month due to a lack of time on the part of the teachers.

\section{Shared understanding of $C B E$}

The degree of understanding among teachers within this team may be qualified as high. All but one teacher named six principles of CBE. For example:

Students have to learn to act independently and to show initiative ... this is very important in their future occupation ... we assess these kinds of competencies every term. (T19)

The agreement among teachers was also strong in that four principles were named by all teachers (principles 2, 3, 4 and 7).

\section{Team learning}

Individual learning activities did not occur very often in this team. Reading and experimenting occurred especially at the beginning of the implementation of CBE, but after everything was settled there was not enough time or urgency to keep on doing this.

Reflection still occurred regularly, which was partly because every integrated project was evaluated at the end. This stimulated teachers to reflect on their own contributions to the learning potential of the project.

Social learning activities seem to have occurred more than individual learning activities. Like in the other teams, observations of others' lessons barely occurred, and only when teachers were receiving training. As one of the teachers explained:

Due to a lack of time, I don't attend colleagues' lessons anymore ... but if I see that the colleague with whom I guide a project acts in a way other than I would do, I immediately discuss this. (T18)

At the beginning of the implementation of CBE, teachers developed and experimented with each other's new projects. Now, teachers regularly meet formally and informally to discuss projects, lessons and students and their progress. As one teacher explained:

Projects are guided by two or three teachers. Mostly, before a project starts, the teachers meet one hour in advance to talk things through. Students know, of course, that teachers have different characters and styles ... but overall we think it is important to be in unison. (T21) 
Table 3. Summary of scores team 3.

\begin{tabular}{lcccc}
\hline Understanding of CBE & \multicolumn{2}{c}{ Team learning } & \multicolumn{2}{c}{ Interdependence } \\
\hline Individual & + & Interpersonal learning activities at workplace & $+/-$ & Task \\
Shared & + & & Goal & + \\
\hline
\end{tabular}

\section{Interdependence}

On average, the task interdependence was considered to be moderate. Two out of four teachers experienced low task interdependence, and two teachers experienced moderate task interdependence. At the beginning of the implementation process, interdependence was higher. As one of the teachers explained:

By now, everyone knows what is expected of him or her ... and if a subject has not been dealt with, we do that part ourselves ... we are all familiar with the occupation and know enough about the different subject areas. (T20)

During the implementation of integrated projects, teachers had to find out together how to fit different subject areas together in assignments. Teachers also had to decide, for example, in what order different assignments could best be offered. At the time of the study, all assignments and theoretical lessons were written down in weekly planning schemes, and teachers could do their jobs more independently of each other.

On average, high goal interdependence was experienced: goal interdependence was regarded as high by three teachers and as moderate by one. All had the impression that the teachers in the team aimed at the same goal of preparing the students for their future occupation. Every teacher stressed the importance of the occupational attitude of the students. Teachers did, however, differ concerning the degree to which they would call each other to account. For example:

I call colleagues to account when I think something goes wrong. When not enough attention is being paid to the attitude of students .... Discussing these kinds of issues has always been important, but especially in CBE ... where students are explicitly assessed on their attitudes. (T20)

And:

I don't think that calling my colleagues to account is part of my task. (T21)

A summary of this team's scores is presented in Table 3.

\section{Cross-case analysis}

\section{Development of a shared understanding through team learning}

Table 4 contains a summary of the findings across the three teams. Our data suggest that the more teachers' engaged in interpersonal learning activities at the workplace - observing others, preparing lessons together, talking about $\mathrm{CBE}$ and formal meetings - the more teachers from the team had a shared understanding of CBE: moderate levels of team learning co-occurred with high levels of shared understanding in teams 2 and 3, whereas a low level of team learning co-occurred with a low level of shared understanding in team 1 . 


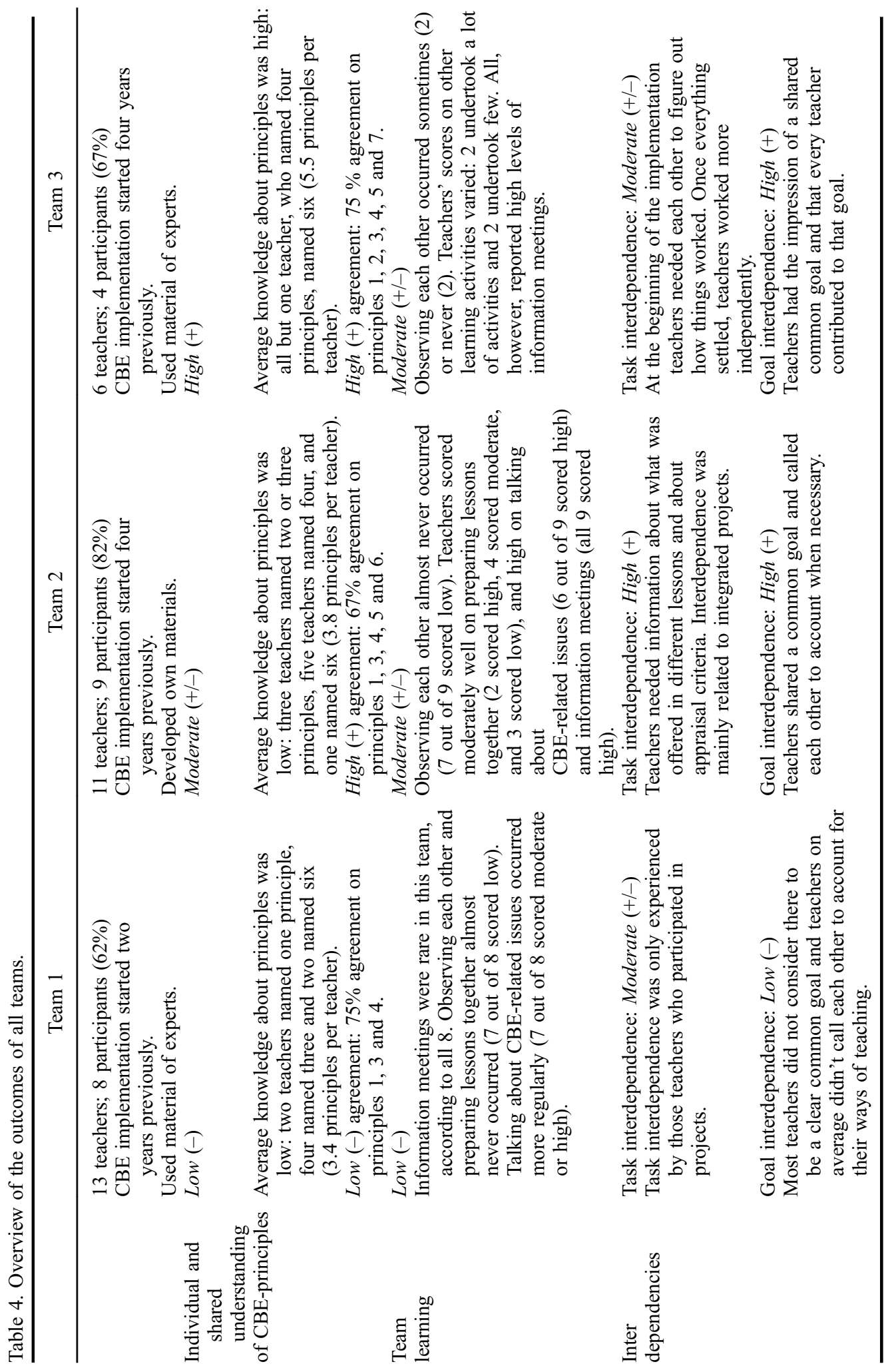


The variation between teams concerning the level of team learning, however, was not very large. That is, one team scored 'low', the others 'moderate'. As is the case in most other Dutch VET institutions (Wesselink et al. 2010), in the VET institution of our study, the development of the CBE way of teaching had to occur alongside the 'traditional' system in which teachers give lectures to students. Probably, this restricted the time teachers had available to spend on their learning and development, and reflecting on their perspectives on teaching.

\section{Task and goal interdependence and social learning}

The more teachers were convinced of their common goal and the fact they needed each other in reaching this goal, the more interpersonal learning activities took place. The degree to which teachers tended to discuss each other's contributions to the goal differed, however, and there appeared to be no formal incentives or punishments if people did not adhere to the common goals. In this sense, goal interdependence seemed to be a matter of individual attitude or team culture. As one teacher from team 2 explained, this might be related to the way the teams were managed within the institution:

Implementation is left to the teams. If it looks good from the outside, and if there are no complaints or problems, one will hear nothing from above. (T11)

It was difficult to detect an association between teachers' task interdependence and team learning. This might be explained by the following: while we expected that task interdependence would increase over time alongside the implementation stage of CBE, and as such stimulate team learning, this appeared not always to be the case. That is, some teachers reported that at the beginning of CBE implementation they needed each other's information and creativity for the development of integrated projects, but later on, when these projects were implemented in the curriculum, they could work more independently.

\section{Understanding of $C B E$ and interdependence}

Finally, we explored whether the more teachers understood what CBE meant and how it should be implemented, the more they would be aware of their common goals and the mutual dependencies between their tasks. However, a shared understanding of CBEprinciples only co-occurred with goal interdependence. The absent association between a shared understanding and task interdependence may be explained by the way this form of interdependence changed during the implementation process; sometimes, it increased, but sometimes it decreased.

\section{Team size and start date of CBE implementation}

The sizes of the teams differed, but showed no clear link with the variation in scores on the three study variables. That is, as Table 4 shows, teams 1 and 2 are of comparable size, but differ from each other what our study variables are concerned. However, when it comes to the start date, we can see that team one, which started last, had the lowest scores on all study variables as well. This finding may suggest that the degree of interdependence among team members, their engagement in team learning activities and their understanding of what $\mathrm{CBE}$ actually means, increase during the implementation process. 


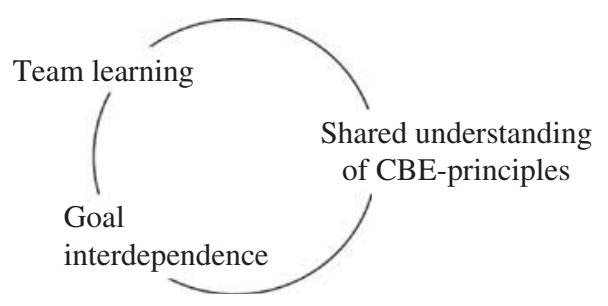

Figure 2. Summary of findings.

\section{Conclusions and discussion}

The goal of our study was to explore to what degree and how task and goal interdependence was related to team learning and consequently a shared understanding within teams about the complex problems they face - in our case the implementation of CBE by teacher teams. As visualized in Figure 2, the more teachers were convinced that they had a common goal, and that they needed each other in achieving the goal (goal interdependence), the more also team learning took place. Moreover, the more team learning activities teachers undertook, the more a shared understanding of CBE-principles those teachers reported. Apparently, teachers needed each other in order to understand what CBE encompasses and to adjust their meanings to each other's. Finally, the circle was completed by the finding that a shared understanding of CBE-principles co-occurred with goal interdependence, implying that the more teachers understand what CBE meant, the greater their awareness of their common goals was.

\section{Theoretical implications}

Our study suggests that the team wherein teachers' work is embedded can play an important role in teachers' learning. Especially the way goals were defined and experienced appeared to be associated by the degree to which teachers engaged into team learning activities. What we also found was that, although a common goal may be present, this not automatically means that it has consequences when team members do not contribute to the attainment of the goal. Our data also suggest that the degree of task interdependence changed over time; it could decrease and increase dependent on the career development of teachers (e.g. in the beginning you need more information from colleagues) or the degree of task maturity of the team (e.g. in the beginning of CBEimplementation teachers needed each other to develop new materials, whereas later on, teachers could just do their jobs individually). These findings call for more research on the complex nature of interdependence, and how exactly goal interdependence can be shaped and stimulated in order to increase team learning.

In a broader perspective, our findings contribute to the existing HRD literature, where, until recently, the focus has been on the individual or the organizational level. The team level, which is in fact a link between the other two, has got relatively little attention (e.g. McCarthy and Garavan 2008). By crossing the boarders between HRD and organizational studies on one hand and educational studies on the other, we contributed to this field of research. In our opinion, the theories about teachers' learning (e.g. Bakkenes, Vermunt, and Wubbels 2010) and educational innovations (e.g. Spillane, Reiser, and Reimer 2002) are to a large degree applicable to other contexts as well. In this sense, we recommend more studies wherein insights from the different disciplines are integrated. Moreover, with 
our study we showed that the educational setting is a suitable setting to study the learning of professionals. While this context is often ignored in organizational research, schools' controlled settings - in terms of relatively homogeneous set of activities and a quite consistent organizational structure - make schools a very suitable research subject regarding human and social capital (Pil and Leana 2009).

\section{Limitations and suggestions for further research}

The first limitation we wish to pay attention to is the cross-sectional nature of our data which made it impossible to draw conclusions on causal relationships between the study variables and to relate this for instance to the maturity of the implementation. Hence, future research should include longitudinal data. This would especially be interesting in the light of the changing nature of task interdependence and its effects on team learning. Second, we did not differentiate between the different team learning activities, nor did we qualify them. It may, however, be that the type of preferred activities changes over time, dependent on the stage of implementation as well. Related to this, there could be more kinds of activities that team members can undertake to develop a shared understanding of the challenges they meet. For future research, it would be interesting to examine the occurrence and effects of different types of team learning activities. Related to this, it would also be interesting to differentiate between different aspects of a shared understanding: in our case for instance, some principles may be more important or central to the concept of CBE than others. Hence, in future research, the quality of the shared understanding could be included as well. Third, the low number of cases, due to the explorative nature of the study, sets limits to the generalizability of our results. For future research, it would be recommended to include a larger sample in the study and to conduct quantitative techniques to validate the associations we found. Fourth, we focused on variables at the team level, while former research indicated that the links between people's perceptions of interdependence and behavioural outcomes partly depend on individual predispositions (e.g. Wageman 2001). Hence, for future research, we recommend taking individual characteristics and their interaction with team characteristics into account. Finally, the organizational context in which the teams were embedded was not taken into consideration. It is to be expected, however, that it had an influence as well. Hence, a more comprehensive picture of the development of a shared understanding of CBE-principles would probably emerge if organizational characteristics like structure, culture or management styles were also taken into account. Related to this, it would be very interesting to replicate our study in a totally different organizational setting.

\section{Practical implications}

On the basis of our results, we make several recommendations for managers and HRD practitioners. First, organizations are recommended to facilitate team members in learning from each other, for our findings showed how hard it can be for employees to find time to learn how to face the complex problems they are facing alongside their core tasks. Therefore, expanding the amount of time employees are allowed to spend observing each other during work or developing materials together is advised. However, there are other ways to stimulate team learning as well. For instance, employees' engagement in team learning activities could be recognized as a natural part of their performance and as such be a topic in performance appraisals. Second, since teachers' engagement in team learning activities co-occurred with goal interdependence, shared goals could be stressed 
formally by management. Awareness of common goals in our cases seemed primarily to be a matter of attitude on the part of the team members. The same appeared to be true for the degree to which teachers held each other responsible for their contributions to achieving the goals. It is imaginable, however, that this contribution may be formalized in terms of task descriptions or team targets, and as such be recognized as a basis of performance appraisal and reward. Third, the finding that a shared understanding of the principles of the new educational concept of CBE co-occurred the awareness of mutual goal dependencies between teachers suggests that it might be worthwhile to invest in providing information to employees concerning the innovation at hand. For instance, as was done in the teams we included in our study, this could be done by organizing information meetings, inviting experts from outside the organization or by making information outside the organization accessible for teams.

\section{References}

Åkerlind, G. S. 2005. "Variation and Commonality in Phenomenographic Research Methods." Higher Education Research \& Development 24: 321-334.

Bakkenes, I., J. D. Vermunt, and T. Wubbels. 2010. "Teacher Learning in the Context of Educational Innovation: Learning Activities and Learning Outcomes of Experienced Teachers." Learning and Instruction 20: 533-548.

Biemans, H., L. Nieuwenhuis, R. F. Poell, M. Mulder, and R. Wesselink. 2004. "Competence-Based VET in The Netherlands: Backgrounds and Pitfalls." Journal of Vocational Education and Training 56: 523-538.

Campion, M. A., G. J. Medsker, and A. C. Higgs. 1993. "Relations Between Work Group Characteristics and Effectiveness: Implications for Designing Effective Work Groups." Personnel Psychology 46: 823-850.

Chinn, C. A., and W. F. Brewer. 1993. "The Role of Anomalous Data in Knowledge Acquisition: A Theoretical Framework and Implications for Science Instruction.” Review of Educational Research 63: 1-49.

Coburn, C. E. 2004. "Beyond Decoupling: Rethinking the Relationship Between the Institutional Environment and the Classroom." Sociology of Education 77: 211-244.

De Bruijn, E. 2012. "Teaching in Innovative Vocational Education in The Netherlands." Teachers and Teaching: Theory and Practice 16: 637-653.

Decuyper, S., F. Dochy, and P. Van de Bossche. 2010. "Grasping the Dynamic Complexity of Team Learning: An Integrative Model for Effective Team Learning in Organisations." Educational Research Review 5: 111-133.

Deutsch, M. 1973. The Resolution of Conflict. New Haven, CT: Yale University Press.

Edmondson, A. 1999. "Psychological Safety and Learning Behavior in Work Teams." Administrative Science Quarterly 44: 350-383.

Griffin, D., P. Shaw, and R. Stacey. 1998. "Speaking of Complexity in Management Theory and Practice." Organization 5: 315-339.

Johnson, D. W., and R. T. Johnson. 1989. Cooperation and Competition: Theory and Research. Edina, MN: Interaction Book Company.

Kiggundu, M. N. 1983. "Task Interdependence and Job Design: Test of a Theory." Organisational Behaviour and Human Performance 31: 145-172.

Kuijpers, M., F. Meijers, and C. Gundy. 2011. "The Relationship Between Learning Environment and Career Competencies of Students in Vocational Education." Journal of Vocational Behavior 78: 21-30.

Kwakman, K. 2003. "Factors Affecting Teachers' Participation in Professional Learning Activities." Teaching and Teacher Education 19: 149-170.

Little, J. W. 2003. "Inside Teacher Community: Representations of Classroom Practice." Teachers College Record 105: 913-945.

Lodders, N. 2013. "Teachers Learning and Innovating Together. Exploring Collective Learning and its Relationship to Individual Learning, Transformational Leadership and Team Performance in Higher Vocational Education." PhD thesis. Twente University, Enschede. 
Lohman, M. C. 2005. "A Survey of Factors Influencing the Engagement of Two Professional Groups in Informal Workplace Learning Activities." Human Resource Development Quarterly 16: $501-521$.

Marsick, V. J., and K. E. Watkins. 2001. "Informal and Incidental Learning." New Directions for Adult and Continuing Education 89: 25-34.

McCarthy, A., and T. N. Garavan. 2008. "Team Learning and Metacognition: A Neglected Area of HRD Research and Practice." Advances in Human Resources Development 10: 509-524.

McLaughlin, M. W. 1997. "Rebuilding Teacher Professionalism in the United States." In Beyond Educational Reform. Bringing Teachers Back In, edited by A. Hargreaves and R. Evans, 77-93. Buckingham: Open University Press.

Meijrink, J. A., P. C. Meijer, N. Verloop, and T. C. M. Bergen. 2009. "Understanding Teacher Learning in Secondary Education: The Relations of Teacher Activities to Changed Beliefs about Teaching and Learning." Teaching and Teacher Education 25: 89-100.

Meirink, J. A., J. Imants, P. C. Meijer, and N. Verloop. 2010. "Teacher Learning and Collaboration in Innovative Teams." Cambridge Journal of Education 40 (2): 161-181.

Miles, B. M., and A. M. Huberman. 1994. Qualitative Data Analysis. 2nd ed. Beverly Hills, CA: Sage.

Mulder, M., T. Weigel, and K. Collins. 2007. "The Concept of Competence in the Development of Vocational Education and Training in Selected EU Member States: A Critical Analysis." Journal of Vocational Education \& Training 59: 51-64.

Nisbett, R. E., and L. Ross. 1980. Human Inference: Strategies and Shortcomings of Social Judgment. Englewood Cliffs: NJ: Prentice-Hall.

Park, S., A. B. Henkin, and R. Egley. 2005. "Teacher Team Commitment, Teamwork and Trust: Exploring Associations." Journal of Educational Administration 43 (5): 462-479.

Pil, F., and C. R. Leana. 2009. "Public Policy: Applying Organizational Research to Public School Reform: The Effects of Teacher Human and Social Capital on Student Performance." Academy of Management Journal 52: 1101-1124.

Putnam, R. T., and H. Borko. 2000. "What Do New Views of Knowledge and Thinking Have to Say About Research on Teacher Learning." Educational Researcher 29: 4-15.

Rivkin, S. G., E. A. Hanushek, and J. F. Kain. 2005. "Teachers, Schools and Academic Achievement." Econometrica 73: 417-458.

Savelsbergh, C. M. J. H., B. I. J. M. van der Heijden, and R. F. Poell. 2009. "The Development and Empirical Validation of a Multidimensional Measurement Instrument for Team Learning." Small Group Research 40: 578-607.

Schaap, H., L. Baartman, and E. De Bruijn. 2012. "Students' Learning Processes during SchoolBased Learning and Workplace Learning in Vocational Education: A Review." Vocations and Learning 5 (2): 99-117.

Seezink, A., and R. F. Poell. 2010. "Continuing Professional Development Needs of Teachers in Schools for Competence-Based Vocational Education: A Case Study from The Netherlands." Journal of European Industrial Training 34: 455-474.

Silins, H. C., and W. R. Mulford. 2002. "Schools as Learning Organisations." Journal of Educational Administration 40: 425-446.

Smith, C., and M. Gillepsie. 2007. "Research on Professional Development and Teacher Change: Implications for Adult Basic Education." Review of Adult Learning and Literacy 7: 205-244.

Spillane, J. P., B. J. Reiser, and T. Reimer. 2002. "Policy Implementation and Cognition: Reframing and Refocusing Implementation Research." Review of Educational Research 72: 387-431.

Sturing, L., H. Biemans, M. Mulder, and E. De Bruijn. 2011. "The Nature of Study Programmes in Vocational Education: Evaluation of the Model for Comprehensive Competence-Based Vocational Education in The Netherlands." Vocations and Learning 4: 191-210.

Tillema, H. 2005. "Collaborative Knowledge Construction in Study Teams of Professionals." Human Resource Development International 8: 81-99.

Tynjälä, P. 2012. "Toward a 3-P Model of Workplace Learning: A Literature Review." Vocations and Learning 6: 11-36.

Van den Berg, N., F. Meijers, and M. Sprengers. 2007. "More Vocational Education and Supplementary Training through Equalization of Costs? An Analysis of a Training and Development Fund in The Netherlands." Human Resource Development International 9: 5-24. 
Van den Bossche, P., W. Gijselaers, M. Segers, and P. A. Kirschner. 2006. "Social and Cognitive Factors Driving Teamwork in Collaborative Learning Environments. Team Learning Beliefs \& Behaviors." Small Group Research 37: 490-521.

Van der Vegt, G., B. Emans, and E. Van de Vliert. 1998. "Motivating Effects of Task and Outcome Interdependence in Work Teams." Group and Organization Management 23: 124-143.

Van der Vegt, G. S., and O. Janssen. 2003. "Joint Impact of Interdependence and Group Diversity on Innovation." Journal of Management 29: 729-751.

van Woerkom, M. 2004. "The Concept of Critical Reflection and Its Implications for Human Resource Development." Advances in Developing Human Resources 6: 178-193.

van Woerkom, M., and M. A. Croon. 2009. "The Relationships Between Team Learning Activities and Team Performance." Personnel Review 38: 560-577.

Wageman, R. 2001. "The Meaning of Interdependence." In Groups at Work: Theory and Research, edited by M. E. Turner, 197-217. Mahwah, NJ: Erlbaum.

Wesselink, R., H. J. A. Biemans, M. Mulder, and E. Van den Elsen. 2007. "Competence-Based VET as Seen by Dutch Researchers." European Journal of Vocational Training 40: 38-51.

Wesselink, R., A. M. Dekker-Groen, H. J. A. Biemans, and M. Mulder. 2010. "Using an Instrument to Analyse Competence-Based Study Programmes: Experiences of Teachers in Dutch Vocational Education and Training." Journal of Curriculum Studies 42: 813-829.

Wilson, J. M., P. S. Goodman, and M. A. Cronin. 2007. "Group Learning." Academy of Management Review 32: 1041-1059.

Yin, R. K. 2003. Case Study Research: Design and Methods. Thousand Oaks, CA: Sage.

Zaccaro, S. J., K. Ely, and M. Shuffler. 2008. "The Leader's Role in Group Learning.” In Work Group Learning, Understanding, Improving, Assessing How Groups Learn in Organizations, edited by V. Vessa and M. London, 15-44. Mahwah, NJ: Lawrence Erlbaum. 